\title{
ANALISIS OVERREACTION PADA SAHAM PERUSAHAAN MANUFAKTUR DI BURSA EFEK INDONESIA (BEI) PERIODE 2005-2009
}

\author{
$\underline{\text { Ari Apriyono }}{ }^{1}$ \\ arie.ap88@gmail.com \\ $\underline{\text { Abdullah Taman }}$
}

Fakultas Ekonomi Universitas Negeri Yogyakarta

\begin{abstract}
ABSTRAK
Penelitian ini bertujuan untuk mengetahui apakah terjadi overreaction terhadap saham perusahaan manufaktur di Bursa Efek Indonesia (BEI) periode 2005-2009 dengan melihat perbedaan rata-rata cumulative abnormal return antara portofolio winner dan portofolio looser. Metode analisis data yang digunakan adalah metode uji statistik parametrik yang digunakan untuk menganalisis perbandingan antara dua nilai rata-rata dengan standar error dari perbedaan rata-rata dua sampel yang tidak berhubungan. Hasil penelitian menunjukkan bahwa tidak terjadi overreaction signifikan. Hal ini didukung dengan adanya hasil uji beda (independent sample t-test) bahwa tidak terdapat perbedaan rata-rata cumulative abnormal return antara portofolio winner dan portofolio looser pada bulan Januari 2005-2009, Februari 2005-2009, Mei 2005-2009, Juni 2005-2009, September 2005-2009, dan Desember 2005-2009 yaitu sebesar 0,399, 0,539, 0,222, 0,487, 0,183, 0,346 dan nilai Significant (2-tailed) 2005-2009 sebesar 0,192 lebih besar dari Level of Significant 5\%.
\end{abstract}

Kata kunci: overreaction, Bursa Efek Indonesia

\section{ABSTRACT}

This study aims to determine whether there is overreaction to the share of manufacturing companies in Indonesia Stock Exchange (IDX) 2005-2009 by seeing the difference in average cumulative abnormal return between a portfolio winner and portfolio looser. Data analysis method used is the method of parametric statistical test used to analyze the comparison between the two average values with the standard error of the mean difference of the two samples were not related. The results showed that there was no significant overreaction. This is supported by the results of different test (independent sample t-test) that there is no difference in the average cumulative abnormal return between a portfolio winner and portfolio looser in January 2005- 2009, February 2005-2009, May 2005-2009, June 2005-2009, September 2005-2009, and December 2005-2009 in the amount of 0.399, 0.539, 0.222, 0.487, 0.183, 0.346 and Significant values (2-tailed) 2005-2009 0.192 greater than 5\% Level of Significant.

Keywords: overreaction, Indonesia Stock Exchange

\footnotetext{
${ }^{1}$ Alumni Prodi Akuntansi Fakultas Ekonomi Universitas Negeri Yogyakarta

${ }^{2}$ Staf Pengajar Jurusan P. Akuntansi Fakultas Ekononi Universitas Negeri Yogyakarta
} 


\section{JURNAL NOMINA / VOLUME II NOMOR II / TAHUN 2013}

\section{A. PENDAHULUAN}

\section{Latar Belakang Masalah}

Berbagai penelitian dalam bidang pasar modal dan mengenai perilaku keuangan (behavioral finance) menyatakan bahwa terdapat beberapa penyimpangan yang terjadi yang dapat mempengaruhi harga saham. Penyimpangan tersebut diantaranya adalah fenomena January effect, fenomena size effect, dan day of the week, dan fenomena Overreaction (De Bond dan Thaler, 1985: 550). Salah satu penyimpangan yang akan dikaji dalam penelitian ini yaitu tentang fenomena Overreaction.

Overreaction ditunjukkan dengan adanya perubahan harga saham dan dapat diukur dengan abnormal return. Implikasi yang terjadi di pasar modal adalah terjadinya pembalikan harga saham sebagai respon atas adanya informasi yang diterima investor, yang membuktikan bahwa pasar telah bereaksi secara berlebihan (overreact). Saham-saham yang biasanya diminati pasar karena mempunyai return tinggi akan menjadi kurang diminati, sedangkan saham-saham yang bernilai rendah dan kurang diminati akan mulai dicari oleh pasar. Kondisi ini menyebabkan return saham yang sebelumnya tinggi menjadi rendah, dan return yang sebelumnya rendah akan menjadi tinggi. Keadaan ini menyebabkan terjadinya abnormal return positif dan negatif.

Penelitian mengenai keberadaan reaksi berlebihan (overreaction) seringkali menggunakan data saham yang dikelompokkan menjadi dua, yaitu kelompok saham (portofolio) looser dan kelompok saham (portofolio) winner. Kelompok saham yang disebut looser yaitu kelompok saham yang konsisten mengalami penurunan besar harga, sedangkan kelompok saham yang disebut kelompok winner yaitu kelompok saham yang konsisten mengalami kenaikan besar harga. Penyebab perubahan besar harga pada saham golongan looser dan saham golongan winner, antara lain disebabkan karena adanya informasi buruk (bad news) dan informasi bagus (good news) yang diterima oleh para pelaku pasar, sehingga para pelaku pasar melakukan reaksi. 
Penelitian yang dilakukan Rahmawati dan Tri Suryani tahun 2005 menemukan bahwa terdapat indikasi reaksi berlebihan (Overreaction) yang ditandai dengan potofolio looser mengungguli potofolio winner. Hal ini dapat memberikan penjelasan bahwa pasar modal di Indonesia khususnya untuk perusahaan sektor manufaktur dalam kondisi efisien pasar bentuk lemah (weak form).

Atas dasar pertimbangan tersebut, penulis akan melakukan penelitian tentang Analisis Overreaction dengan periode pengamatan pada tahun 2005 sampai dengan 2009 dan memfokuskan pengamatan hanya pada perusahaan manufaktur yang tergabung dalam Indeks LQ45 pada Bursa Efek Indonesia. Judul penelitian yang diambil adalah "Analisis Overreaction pada Saham Perusahaan Manufaktur di Bursa Efek Indonesia (BEI) Periode 2005-2009”.

\section{B. KAJIAN LITERATUR}

\section{Abnormal Return}

Return tidak normal (abnormal return) merupakan kelebihan dari return yang sesungguhnya terjadi terhadap return normal. Return normal merupakan return ekspektasi (jogiyanto, 2008: 549). Dengan demikian return tidak normal (abnormal return) adalah selisih antara return sesungguhnya yang terjadi dengan return ekspektasi.

Pada penelitian ini, pengujian terhadap variabel return tidak normal (abnormal return) tidak dilakukan untuk tiap-tiap sekuritas, tetapi dilakukan secara agregat dengan menguji rata-rata akumulasi return ridak normal (Cumulative Abnormal Return/CAR) seluruh sekuritas secara cross-section. Rata-rata akumulasi return ridak normal ini dilakukan untuk melihat apakah ada perbedaan kinerja portofolio winner dan portofolio looser. Pembentukan portofolio winner dan partofolio looser adalah berdasarkan ranking return tidak normal harian yang diakumulasikan setiap periode pembentukan (periode 1: Januari 2005 sampai Desember 2005, periode 2 : Januari 2006 sampai Desember 2006, periode 3: Januari 2007 sampai Desember 2007, periode 4: Januari 2008 sampai Desember 
2008). Rata-rata akumulasi return ridak normal dihitung dengan menggunakan return tidak normal model market-adjusted model dengan menggunakan rumus (Jogiyanto, 2008: 550):

$R_{i, t}=\frac{P_{i, t}-P_{i, t-1}}{P_{i, t-1}}$

$R_{\mathrm{M} \cdot \mathrm{t}}=\frac{\left(\operatorname{In} \cdot \mathrm{LQ} 45_{\mathrm{t}}-\mathrm{In} \cdot \mathrm{LQ} 45_{\mathrm{t}-1}\right)}{\operatorname{In} \cdot \mathrm{LQ} 45_{\mathrm{t}-1}}$

$\mathrm{RTN}_{\mathrm{i}, \mathrm{t}}=\mathrm{R}_{\mathrm{i}, \mathrm{t}}-\mathrm{R}_{\mathrm{M}, \mathrm{t}}$

$\operatorname{ARTN}_{\text {i.t }}=\sum \mathrm{RTN}_{\mathrm{i}, \mathrm{t}}$

Keterangan:

$\mathrm{R}_{\mathrm{i}, \mathrm{t}} \quad \quad=$ return saham ke-i pada hari ke- $\mathrm{t}$

$\mathrm{P}_{\mathrm{i} . \mathrm{t}} \quad=$ harga saham ke-i pada hari ke-t

$\mathrm{P}_{\mathrm{i}, \mathrm{t}-1} \quad=$ harga saham ke-i pada hari ke- $\mathrm{t}-1$

$\mathrm{R}_{\mathrm{M} . \mathrm{t}} \quad=$ return pasar menggunakan indeks saham LQ45 pada hari ke-t

In. $\mathrm{LQ}_{\mathrm{t}} \quad$ = indeks harga saham harian LQ45 pada hari ke-t

In. $\mathrm{LQ}_{4-1} \quad$ = indeks harga saham harian LQ45 pada hari ke-t-1

RTN $_{\text {it }} \quad=$ return tidak normal saham ke-i pada hari ke-t

$\mathrm{R}_{\mathrm{i}, \mathrm{t}} \quad$ = return saham ke-i pada hari ke- $\mathrm{t}$

$\mathrm{R}_{\mathrm{M} . \mathrm{t}} \quad=$ return indeks pasar pada hari ke-t

ARTN $_{\text {it }}=$ akumulasi return tidak normal saham ke-i pada hari ke$\mathrm{t}$

$\mathrm{k} \quad=$ jumlah sekuritas

\section{Kerangka Berfikir}

Keberadaan reaksi berlebihan (overreaction) seringkali menggunakan data saham yang dikelompokkan menjadi dua, yaitu kelompok saham (portofolio) looser dan kelompok saham (portofolio) winner. Penyebab perubahan besar harga pada saham golongan loser dan saham golongan winner, antara lain disebabkan karena adanya informasi 
buruk (bad news) dan informasi bagus (good news) yang diterima oleh para pelaku pasar, sehingga para pelaku pasar melakukan reaksi. Reaksi berlebihan ditunjukkan dengan adanya perubahan harga saham dengan menggunakan return dari sekuritas yang bersangkutan. Reaksi ini dapat diukur dengan abnormal return dari sekuritas yang ada. Return saham ini akan menjadi terbalik dalam fenomena reaksi berlebihan. Saham-saham yang biasanya diminati pasar dan mempunyai return tinggi, akan menjadi kurang diminati. Sedangkan saham-saham yang bernilai rendah dan kurang diminati akan mulai dicari oleh pasar. Kondisi ini akan mengakibatkan return saham yang sebelumnya tinggi menjadi rendah, dan return yang sebelumnya rendah akan menjadi tinggi. Keadaan ini akan menyebabkan terjadinya abnormal return positif dan negatif. Sehinga perbedaan inilah yang akan menyebabkan terjadinya overreaction. Hipotesis penelitian ini adalah terjadi overreaction terhadap saham perusahaan manufaktur di Bursa Efek Indonesia (BEI) periode 2005-2009 dengan melihat terdapat perbedaan rata-rata cumulative abnormal return antara portofolio winner dan partofolio looser.

\section{METODE PENELITIAN}

\section{Tempat dan Waktu Penelitian}

Tempat penelitian dilakukan di Bursa Efek Indonesia melalui Pusat Data Pasar Modal PPA UGM dan di Indonesian Stock Excange (IDX) melalui situs www.idx.co.id, sedangkan waktu penelitian dilaksanakan bulan Januari sampai dengan bulan Februari 2011.

\section{Jenis Penelitian}

Jenis penelitian adalah penelitian komparatif karena bertujuan untuk mengetahui nilai dalam satu variabel atau lebih pada sampel yang berbeda (Sugiyono, 2011:88). Berdasarkan jenis datanya, penelitian ini berbentuk penelitian kuantitatif yaitu penelitian yang datanya berbentuk angka-angka atau data kualitatif yang diangkakan (Sugiyono, 2011: 23).

\section{Populasi dan Sampel}

Data yang akan digunakan dalam penelitian ini diperoleh dari publikasi di Bursa Efek Indonesia. Menurut Nur Indriantoro dan Bambang 
Supomo, "Populasi (population), yaitu sekelompok orang, kejadian atau segala sesuatu yang mempunyai karakteristik tertentu" (Nur Indriantoro dan Bambang Supomo, 2002: 115). Populasi dalam penelitian ini adalah seluruh perusahaan manufaktur yang terdaftar di Bursa Efek Indonesia tahun 2005-2009. Sedangkan sampel yang digunakan dalam penelitian ini diambil dengan menggunakan metode purposive sampling. Metode ini menetapkan bahwa setiap elemen tidak mempunyai kesempatan yang sama untuk menjadi sampel penelitian, tetapi hanya elemen yang memenuhi syarat tertentu saja yang dapat dipilih.

\section{Metode Pengumpulan Data}

Data yang digunakan dalam penelitian ini adalah data sekunder yaitu data perusahaan manufaktur yang tergabung dalam Indeks LQ45 di Bursa Efek Indonesia (BEI) periode 2005-2009. Data tersebut berasal dari berbagai sumber, antara lain: Pusat Data Pasar Modal PPA UGM, Indonessian Stock Excenge (IDX) melalui situs www.idx.co.id, literatur yang berhubungan, serta sumber pendukung lainnya. Metode yang digunakan dalam penelitian ini adalah metode dokumentasi dan metode studi pustaka. Jenis data yang diperlukan antara lain:

a. Nama perusahaan dan harga saham perusahaan manufaktur yang tergabung dalam Indeks LQ45 tanggal 1 Januari 2005 sampai dengan 31 Desember 2009.

b. Indeks harga saham LQ45 tanggal 1 Januari 2005 sampai dengan 31 Desember 2009.

\section{Teknik Analisis Data}

\section{a. Statistik Deskriptif}

Statistik Deskriptif merupakan proses tranformasi data penelitian dalam bentuk tabulasi sehingga mudah dipahami dan diinterpretasikan (Nur Indriantoro dan Bambang Supomo, 2002:17).

Pada penelitian ini akan digambarkan atau dideskripsikan data dari masing-masing variabel yang telah diolah sehingga dapat dilihat nilai terendah (minimum), nilai tertinggi (maximum), rata-rata (mean), 
dan deviasi standar (std. deviation) dari masing-masing variabel yang akan diteliti.

\section{b. Uji Normalitas}

Uji normalitas adalah pengujian data untuk melihat apakah nilai residual terdistribusi normal atau tidak (Imam Ghazali, 2011:29). Data yang berdistribusi normal akan memperkecil kemungkinan terjadinya bias. Dalam penelitian ini, untuk mengetahui kenormalan distribusi data menggunakan Kolmogorov-Smirnov Test melalui program SPSS 21 for windows. Apa bila nilai Asymp. Sig. suatu variabel lebih besar dari level of significant 5\% (> 0.050) maka variabel tersebut terdistribusi normal, sedangkan jika nilai Asymp. Sig. suatu variabel lebih kecil dari level of significant $5 \%(<0.050)$ maka variabel tersebut tidak terdistribusi dengan normal.

\section{c. Uji Hipotesis}

Untuk menguji Hipotesis bahwa apakah ada tingkat signifikansi antara average portofolio winner dibandingkan dengan portofolio loser dihitung menggunakan uji beda (independent t-test) melalui program SPSS 21 for Windows untuk menguji hipotesis. Independen t-test merupakan sebuah metode uji statistik parametrik yang digunakan untuk menganalisis perbandingan dua sampel yang tidak berpasangan. Berikut ini merupakan langkah-langkah yang digunakan dalam menguji hipotesis:

1) Menghitung Return Saham

$$
R_{i, t}=\frac{P_{i, t}-P_{i, t-1}}{P_{i, t-1}}
$$

Keterangan:

$\mathrm{R}_{\mathrm{i}, \mathrm{t}} \quad=$ return saham ke-i pada hari ke-t

$\mathrm{P}_{\mathrm{i} . \mathrm{t}} \quad=$ harga saham ke-i pada hari ke-t

$P_{\mathrm{i}, \mathrm{t}-1}=$ harga saham ke-i pada hari ke- $\mathrm{t}-1$

(Jogiyanto, 2008: 550) 
2) Menghitung Return Pasar (Return Market)

$$
\mathrm{R}_{\mathrm{M} . \mathrm{t}}=\frac{\left(\operatorname{In} . \mathrm{LQ} 45_{\mathrm{t}}-\text { In. LQ45 } 5_{\mathrm{t}-1}\right)}{\operatorname{In} . \mathrm{LQ} 45_{\mathrm{t}-1}}
$$

Keterangan:

$\mathrm{R}_{\mathrm{M} . \mathrm{t}}=$ return pasar menggunakan indeks saham LQ45 pada

hari ke-t

In. $\mathrm{LQ}_{\mathrm{t}} \quad$ = indeks harga saham harian LQ45 pada hari ke-t

In. LQ45 $_{\mathrm{t}-1}=$ indeks harga saham harian LQ45 pada hari ke-t-1

(Jogiyanto, 2008: 555)

3) Menghitung Return Tidak Normal (Abnormal Return)

$$
\mathrm{RTN}_{\mathrm{it}}=\mathrm{R}_{\mathrm{i}, \mathrm{t}}-\mathrm{R}_{\mathrm{M}, \mathrm{t}}
$$

Keterangan:

RTN $_{\text {i.t }}=$ return tidak normal saham ke-i pada hari ke-t

$\mathrm{R}_{\mathrm{i}, \mathrm{t}} \quad=$ return saham ke-i pada hari ke-t

$\mathbf{R}_{\mathrm{M} . \mathrm{t}} \quad=$ return pasar pada hari ke- $\mathrm{t}$

(Jogiyanto, 2008: 550)

4) Menghitung Akumulasi Return Tidak Normal (Cumulative Abnormal Return/CAR). Perhitungan ini untuk menentukan portofolio winner dan portofolio looser yang diurutkan 7 teratas merupakan portofolio winner dan 7 terbawah merupakan portofolio looser.

$$
\operatorname{ARTN}_{\text {i.t }}=\sum \operatorname{RTN}_{\mathrm{i}, \mathrm{t}}
$$

Keterangan:

$\mathrm{ARTN}_{\mathrm{it}}=$ akumulasi return tidak normal saham ke-i pada hari ke-

$\mathrm{t}$

(Jogiyanto, 2008: 564)

5) Menghitung perbedaan rata-rata cumulative abnormal return (CAR) portofolio looser dan portofolio winner. Pengujian 
dilakukan dengan independent sample t-test pada level of significant $5 \%$.

$$
\mathrm{t}=\frac{\overline{\mathrm{CAR}_{\mathrm{W}}}-\overline{\mathrm{CAR}_{\mathrm{L}}}}{\sqrt{\frac{\mathrm{S}_{\mathrm{W}}^{2}}{\mathrm{~S}_{\mathrm{W}}^{2}}+\frac{\mathrm{S}_{\mathrm{L}}^{2}}{\mathrm{~S}_{\mathrm{L}}^{2}}}}
$$

Keterangan:

$=$ Pengujian statistik independen t-test terhadap perbedaan rata-rata CAR portofolio winner dan portofolio looser.

$\overline{C A R_{W}} \quad=$ rata-rata $\mathrm{CAR}$ portofolio winner

$\overline{C A R_{L}} \quad=$ rata-rata $\mathrm{CAR}$ portofolio looser

$S_{W}{ }^{2} \quad=$ Varians dari rata-rata CAR portofolio winner.

$S_{L}{ }^{2} \quad=$ Varians dari rata-rata CAR portofolio looser.

(Sugiyono, 2010: 138)

6) Membuat kriteria dan kesimpulan pengujian sebagai berikut:

Sebelum menganalisis uji beda $t$-test peneliti harus menguji dahulu asumsi apakah variance populasi kedua sampel tersebut sama (equal variances assumed) ataukah berbeda (equal variances not assumed) dengan melihat nilai levene test (Imam Ghozali, 2011: 66). Jika probabilitas levene's test pada kolom Significant > 0,05 maka variance sama. Dengan demikian analisis uji beda $t$-test harus menggunakan asumsi equal variances assumed pada kolom Sig. (2-tailed). Jika probabilitas levene's test pada kolom Significant $<0,05$ maka variance berbeda. Dengan demikian analisis uji beda t-test harus menggunakan asumsi equal variances not assumed pada kolom Sig.(2-tailed).

a) Apabila nilai $t$-test pada kolom Significant (2 tailed) > level of significant $(\alpha=5 \%)$, maka tidak terdapat perbedaan rata-rata 
cumulative abnormal return antara portofolio winner dan portofolio looser.

b) Apabila nilai t-test pada kolom Significant (2 tailed) < level of significant $(\alpha=5 \%)$, maka terdapat perbedaan rata-rata cumulative abnormal return antara portofolio winner dan portofolio looser.

\section{HASIL PENELITIAN DAN PEMBAHASAN}

\section{Hasil Analisis Statistik Deskriptif}

Tabel Statistik Deskriptif Portofolio Winner

\begin{tabular}{|l|r|r|r|r|r|}
\hline & $N$ & \multicolumn{1}{|c|}{ Minimum } & Maximum & \multicolumn{1}{c|}{ Mean } & Std. Deviation \\
\hline JAN & 7 & $-0,0928$ & 0,5125 & 0,267014 & 0,2070044 \\
FEB & 7 & $-0,2313$ & 0,6043 & 0,201243 & 0,2955398 \\
MART & 7 & $-0,1289$ & 0,3177 & 0,085071 & 0,1416811 \\
APRIL & 7 & $-0,0294$ & 0,3053 & 0,158400 & 0,1159740 \\
MEI & 7 & 0,0998 & 0,5929 & 0,323286 & 0,2021069 \\
JUNI & 7 & $-0,1042$ & 0,3004 & 0,084057 & 0,1721365 \\
JULI & 7 & $-0,0511$ & 0,5065 & 0,258414 & 0,1907501 \\
AGUST & 7 & $-0,4361$ & 0,3564 & 0,080143 & 0,3029568 \\
SEPT & 7 & $-0,4883$ & 0,4193 & 0,101057 & 0,2971682 \\
OKT & 7 & $-0,5121$ & 0,7214 & 0,234514 & 0,4088500 \\
NOV & 7 & $-0,1243$ & 0,3535 & 0,046529 & 0,1842958 \\
DES & 7 & $-0,2695$ & 0,8287 & 0,188486 & 0,4084825 \\
Valid N (listwise) & 7 & & & & \\
\hline
\end{tabular}

Dari Tabel Statistik Deskriptif Portofolio Winner ditemukan nilai portofolio winner pada kolom minimum menunjukkan nilai minimum terendah sebesar -0,5121 dan nilai minimum tertinggi sebesar 0,0998 pada bulan Oktober dan Mei, pada kolom maximum menunjukkan nilai maximum terendah sebesar 0,3004 dan nilai maximum tertinggi sebesar 0,8287 pada bulan Juni dan Desember, pada kolom mean menunjukkan nilai mean terendah sebesar 0,046529 dan nilai mean tertinggi sebesar 0,323286 pada bulan November dan Mei, pada kolom std. deviation menunjukkan nilai deviasi standar terendah sebesar 0,1159740 dan nilai deviesi standar tertinggi sebesar 0,4088500 pada bulan April dan Oktober. 
Tabel Statistik Deskriptif Portofolio Looser

\begin{tabular}{|l|r|r|r|r|r|}
\hline & $N$ & Minimum & Maximum & \multicolumn{1}{|c|}{ Mean } & Std. Deviation \\
\hline JAN & 7 & $-0,3302$ & 0,6314 & 0,139357 & 0,3258997 \\
FEB & 7 & $-0,0363$ & 0,2789 & 0,124643 & 0,1235499 \\
MART & 7 & $-0,4885$ & 0,2074 & $-0,230286$ & 0,2845290 \\
APRIL & 7 & $-0,4741$ & 0,1736 & $-0,145771$ & 0,2409873 \\
MEI & 7 & $-0,0599$ & 0,3847 & 0,203014 & 0,1416536 \\
JUNI & 7 & $-0,3437$ & 0,3073 & $-0,005000$ & 0,2771855 \\
JULI & 7 & $-0,4776$ & 0,0812 & $-0,192271$ & 0,1978529 \\
AGUST & 7 & $-0,5813$ & 0,0181 & $-0,277500$ & 0,2373499 \\
SEPT & 7 & $-0,4368$ & 0,1414 & $-0,085671$ & 0,1848246 \\
OKT & 7 & $-0,8671$ & $-0,0588$ & $-0,341214$ & 0,2771988 \\
NOV & 7 & $-0,7386$ & 0,0428 & $-0,257243$ & 0,3147203 \\
DES & 7 & $-0,2377$ & 0,2786 & 0,017229 & 0,2148113 \\
Valid N (listwise) & 7 & & & \\
\hline
\end{tabular}

Dari Tabel Statistik Deskriptif Portofolio Looser ditemukan nilai portofolio looser pada kolom minimum menunjukkan nilai minimum terendah sebesar $-0,8671$ dan nilai minimum tertinggi sebesar $-0,0363$ pada bulan Oktober dan Februari, pada kolom maximum menunjukkan nilai maximum terendah sebesar -0,0588 dan nilai maximum tertinggi sebesar 0,6314 pada bulan Oktober dan Januari, pada kolom mean menunjukkan nilai mean terendah sebesar $-0,341214$ dan nilai mean tertinggi sebesar 0,203014 pada bulan Oktober dan Mei, pada kolom std. deviation menunjukkan nilai deviasi standar terendah sebesar 0,1235499 dan nilai deviesi standar tertinggi sebesar 0,3258997 pada bulan Februari dan Januari.

\section{Hasil Uji Normalitas}

Tabel Hasil Uji Normalitas Kolmogorov-Smirnov Portofolio Winner

\begin{tabular}{|c|c|c|c|c|c|c|c|c|c|c|c|c|c|}
\hline & JAN & FEB & MAR & APR & MEI & JUN & JULI & AGU & SEP & OKT & NOV & DES \\
\hline \multicolumn{2}{|l|}{$\mathrm{N}$} & 7 & 7 & 7 & 7 & 7 & 7 & 7 & 7 & 7 & 7 & 7 & 7 \\
\hline \multirow{2}{*}{$\begin{array}{l}\text { Normal } \\
\text { Parameters }\end{array}$} & Mean & 0,267 & 0,201 & 0,085 & 0,158 & 0,323 & 0,084 & 0,258 & 0,080 & 0,101 & 0,234 & 0,046 & 0,188 \\
\hline & $\begin{array}{l}\text { Std. } \\
\text { Deviation }\end{array}$ & 0,207 & 0,295 & 0,142 & 0,116 & 0,202 & 0,172 & 0,191 & 0,303 & 0,297 & 0,409 & 0,184 & 0,408 \\
\hline \multirow{3}{*}{$\begin{array}{l}\text { Most Extreme } \\
\text { Differences }\end{array}$} & Absolute & 0,157 & 0,147 & 0,163 & 0,239 & 0,246 & 0,280 & 0,161 & 0,209 & 0,275 & 0,216 & 0,227 & 0,242 \\
\hline & Positive & 0,118 & 0,134 & 0,163 & 0,138 & 0,246 & 0,280 & 0,161 & 0,181 & 0,142 & 0,121 & 0,227 & 0,242 \\
\hline & Negative & $-0,157$ & $-0,147$ & $-0,135$ & $-0,239$ & $-0,231$ & $-0,171$ & $-0,145$ & $-0,209$ & $-0,275$ & $-0,216$ & $-0,177$ & $-0,140$ \\
\hline \multicolumn{2}{|c|}{ Kolmogorov-Smirnov Z } & 0,415 & 0,390 & 0,431 & 0,633 & 0,651 & 0,740 & 0,425 & 0,553 & 0,727 & 0,571 & 0,600 & 0,639 \\
\hline \multicolumn{2}{|c|}{ Asymp. Sig. (2-tailed) } & 0,995 & 0,998 & 0,992 & 0,817 & 0,791 & 0,644 & 0,994 & 0,920 & 0,666 & 0,900 & 0,864 & 0,809 \\
\hline
\end{tabular}


Berdasarkan uji normalitas yang telah dilakukan dengan menggunakan uji normalitas Kolmogorov-Smirnov portofolio winner nilai Asymp Sig. (2-tailed) tertinggi sebesar 0,998 pada bulan Februari dan nilai terendah sebesar 0,664 pada bulan Juni, sedangkan pada uji normalitas Kolmogorov-Smirnov portofolio Looser nilai Asymp Sig. (2-tailed) tertinggi sebesar 0,994 pada bulan Januari dan nilai terendah sebesar 0,633 pada bulan Maret, dari hasil tersebut nilai Asymp Sig. (2-tailed) lebih besar dari level of significant $5 \%(>0,050)$. Hal ini berarti data yang digunakan pada penelitian ini terdistribusi secara normal.

\section{Hasil Uji Hipotesis}

Tabel Hasil Uji Hipotesis independent sample t-test 2005-2009

\begin{tabular}{|c|c|c|c|c|c|c|c|c|c|c|}
\hline & & \multicolumn{2}{|c|}{$\begin{array}{l}\text { Levene's Test } \\
\text { for Equality } \\
\text { of Variances }\end{array}$} & \multicolumn{7}{|c|}{ t-test for Equality of Means } \\
\hline & & \multirow[t]{2}{*}{$F$} & \multirow[t]{2}{*}{ Sig. } & \multirow[t]{2}{*}{$t$} & \multirow[t]{2}{*}{$d f$} & \multirow[t]{2}{*}{$\begin{array}{l}\text { Sig. }(2- \\
\text { tailed) }\end{array}$} & \multirow[t]{2}{*}{$\begin{array}{c}\text { Mean } \\
\text { Difference }\end{array}$} & \multirow[t]{2}{*}{$\begin{array}{l}\text { Std. Error } \\
\text { Difference }\end{array}$} & \multicolumn{2}{|c|}{$\begin{array}{c}95 \% \text { Confidence Interval } \\
\text { of the Difference }\end{array}$} \\
\hline & & & & & & & & & Lower & Upper \\
\hline \multirow{2}{*}{ JAN } & Equal variances assumed & 1,202 & 0,294 & 0,875 & 12 & 0,399 & 0,1276571 & 0,1459263 & $-0,1902890$ & 0,4456033 \\
\hline & Equal variances not assumed & & & 0,875 & 10,164 & 0,402 & 0,1276571 & 0,1459263 & $-0,1967786$ & 0,4520929 \\
\hline \multirow{2}{*}{ FEB } & Equal variances assumed & 3,159 & 0,101 & 0,633 & 12 & 0,539 & 0,0766000 & 0,1210716 & $-0,1871924$ & 0,3403924 \\
\hline & Equal variances not assumed & & & 0,633 & 8,035 & 0,545 & 0,0766000 & 0,1210716 & $-0,2023800$ & 0,3555800 \\
\hline \multirow{2}{*}{ MAR } & Equal variances assumed & 6,170 & 0,029 & 2,625 & 12 & 0,022 & 0,3153571 & 0,1201370 & 0,0536011 & 0,5771132 \\
\hline & Equal variances not assumed & & & 2,625 & 8,803 & 0,028 & 0,3153571 & 0,1201370 & 0,0426590 & 0,5880553 \\
\hline \multirow{2}{*}{ APRI } & Equal variances assumed & 3,318 & 0,094 & 3,009 & 12 & 0,011 & 0,3041714 & 0,1010833 & 0,0839298 & 0,5244130 \\
\hline & Equal variances not assumed & & & 3,009 & 8,638 & 0,015 & 0,3041714 & 0,1010833 & 0,0740346 & 0,5343082 \\
\hline \multirow{2}{*}{ MEI } & Equal variances assumed & 3,658 & 0,080 & 1,289 & 12 & 0,222 & 0,1202714 & 0,0932837 & $-0,0829763$ & 0,3235191 \\
\hline & Equal variances not assumed & & & 1,289 & 10,749 & 0,224 & 0,1202714 & 0,0932837 & $-0,0856313$ & 0,3261742 \\
\hline \multirow{2}{*}{ JUN } & Equal variances assumed & 5,525 & 0,037 & 0,722 & 12 & 0,484 & 0,0890571 & 0,1233246 & $-0,1796442$ & 0,3577585 \\
\hline & Equal variances not assumed & & & 0,722 & 10,029 & 0,487 & 0,0890571 & 0,1233246 & $-0,1856207$ & 0,3637350 \\
\hline \multirow{2}{*}{ JUL } & Equal variances assumed & 0,000 & 0,989 & 4,339 & 12 & 0,001 & 0,4506857 & 0,1038759 & 0,2243597 & 0,6770118 \\
\hline & Equal variances not assumed & & & 4,339 & 11,984 & 0,001 & 0,4506857 & 0,1038759 & 0,2243262 & 0,6770453 \\
\hline \multirow{2}{*}{$\mathrm{AGU}$} & Equal variances assumed & 0,395 & 0,542 & 2,459 & 12 & 0,030 & 0,3576429 & 0,1454637 & 0,0407047 & 0,6745810 \\
\hline & Equal variances not assumed & & & 2,459 & 11,350 & 0,031 & 0,3576429 & 0,1454637 & 0,0386797 & 0,6766060 \\
\hline \multirow{2}{*}{ SEP } & Equal variances assumed & 0,550 & 0,472 & 1,412 & 12 & 0,183 & 0,1867286 & 0,1322708 & $-0,1014648$ & 0,4749220 \\
\hline & Equal variances not assumed & & & 1,412 & 10,038 & 0,188 & 0,1867286 & 0,1322708 & $-0,1078392$ & 0,4812963 \\
\hline \multirow{2}{*}{ OKT } & Equal variances assumed & 0,717 & 0,414 & 3,084 & 12 & 0,009 & 0,5757286 & 0,1866997 & 0,1689448 & 0,9825123 \\
\hline & Equal variances not assumed & & & 3,084 & 10,554 & 0,011 & 0,5757286 & 0,1866997 & 0,1626761 & 0,9887810 \\
\hline \multirow{2}{*}{ NOV } & Equal variances assumed & 3,730 & 0,077 & 2,204 & 12 & 0,048 & 0,3037714 & 0,1378477 & 0,0034272 & 0,6041157 \\
\hline & Equal variances not assumed & & & 2,204 & 9,682 & 0,053 & 0,3037714 & 0,1378477 & $-0,0047453$ & 0,6122882 \\
\hline \multirow{2}{*}{ DES } & Equal variances assumed & 1,601 & 0,230 & 0,982 & 12 & 0,346 & 0,1712571 & 0,1744386 & $-0,2088120$ & 0,5513262 \\
\hline & Equal variances not assumed & & & 0,982 & 9,083 & 0,352 & 0,1712571 & 0,1744386 & $-0,2228028$ & 0,5653171 \\
\hline
\end{tabular}

Berdasarkan tabel tersebut maka dapat ditarik kesimpulan pengujian sebagai berikut: 


\section{JURNAL NOMINA / VOLUME II NOMOR II / TAHUN 2013}

\section{a. Januari 2005-2009}

Hasil pengujian independent sample t-test menunjukkan nilai $F$ hitung levence's test sebesar 1,202 dan nilai Significant sebesar 0,294 karena probabilitas $>0,050$ maka memiliki variance yang sama, sehingga analisis uji beda t-test menggunakan asumsi equal variance assumed. Dari kolom t-test terlihat bahwa nilai $t$ pada equal variance assumed sebesar 0,875 dan nilai Significant (2-tailed) sebesar 0,399 lebih besar dari level of significant 5\% (0,399>0,050). Dengan demikian dapat disimpulkan bahwa tidak terdapat perbedaan rata-rata abnormal return antara portofolio winner dan portofolio looser.

\section{b. Februari 2005-2009}

Hasil pengujian independent sample t-test menunjukkan nilai $F$ hitung levence's test sebesar 3,159 dan nilai Significant sebesar 0,101 karena probabilitas $>0,050$ maka memiliki variance yang sama, sehingga analisis uji beda $t$-test menggunakan asumsi equal variance assumed. Dari kolom $t$-test terlihat bahwa nilai $t$ pada equal variance assumed sebesar 0,633 dan nilai Significant (2-tailed) sebesar 0,539 lebih besar dari level of significant 5\% (0,539>0,050). Dengan demikian dapat disimpulkan bahwa tidak terdapat perbedaan rata-rata abnormal return antara portofolio winner dan portofolio looser.

\section{c. Maret 2005-2009}

Hasil pengujian independent sample t-test menunjukkan nilai $F$ hitung levence's test sebesar 6,170 dan nilai Significant sebesar 0,029 karena probabilitas <0,050 maka memiliki variance yang berbeda, sehingga analisis uji beda $t$-test menggunakan asumsi equal variance not assumed. Dari kolom $t$-test terlihat bahwa nilai $t$ pada equal variance not assumed sebesar 2,625 dan nilai Significant (2-tailed) sebesar 0,028 lebih kecil dari level of significant $5 \%(0,028<0,050)$. Dengan demikian dapat disimpulkan bahwa terdapat perbedaan ratarata abnormal return antara portofolio winner dan portofolio looser. 


\section{JURNAL NOMINA / VOLUME II NOMOR II / TAHUN 2013}

\section{d. April 2005-2009}

Hasil pengujian independent sample t-test menunjukkan nilai $F$ hitung levence's test sebesar 3,318 dan nilai Significant sebesar 0,094 karena probabilitas $>0,050$ maka memiliki variance yang sama, sehingga analisis uji beda t-test menggunakan asumsi equal variance assumed. Dari kolom t-test terlihat bahwa nilai $t$ pada equal variance assumed sebesar 3,009 dan nilai Significant (2-tailed) sebesar 0,011 lebih kecil dari level of significant $5 \% \quad(0,011<0,050)$. Dengan demikian dapat disimpulkan bahwa terdapat perbedaan rata-rata abnormal return antara portofolio winner dan portofolio looser.

\section{e. Mei 2005-2009}

Hasil pengujian independent sample t-test menunjukkan nilai $F$ hitung levence's test sebesar 3,658 dan nilai Significant sebesar 0,080 karena probabilitas >0,050 maka memiliki variance yang sama, sehingga analisis uji beda $t$-test menggunakan asumsi equal variance assumed. Dari kolom $t$-test terlihat bahwa nilai $t$ pada equal variance assumed sebesar 1,289 dan nilai Significant (2-tailed) sebesar 0,222 lebih besar dari level of significant 5\% (0,222>0,050). Dengan demikian dapat disimpulkan bahwa tidak terdapat perbedaan rata-rata abnormal return antara portofolio winner dan portofolio looser.

\section{f. Juni 2005-2009}

Hasil pengujian independent sample t-test menunjukkan nilai $F$ hitung levence's test sebesar 5,525 dan nilai Significant sebesar 0,037 karena probabilitas <0,050 maka memiliki variance yang berbeda, sehingga analisis uji beda $t$-test menggunakan asumsi equal variance not assumed. Dari kolom $t$-test terlihat bahwa nilai $t$ pada equal variance not assumed sebesar 0,722 dan nilai Significant (2-tailed) sebesar 0,487 lebih besar dari level of significant $5 \%(0,487>0,050)$. Dengan demikian dapat disimpulkan bahwa tidak terdapat perbedaan rata-rata abnormal return antara portofolio winner dan portofolio looser. 


\section{JURNAL NOMINA / VOLUME II NOMOR II / TAHUN 2013}

\section{g. Juli 2005-2009}

Hasil pengujian independent sample t-test menunjukkan nilai $F$ hitung levence's test sebesar 0,000 dan nilai Significant sebesar 0,989 karena probabilitas $>0,050$ maka memiliki variance yang sama, sehingga analisis uji beda $t$-test menggunakan asumsi equal variance assumed. Dari kolom t-test terlihat bahwa nilai $t$ pada equal variance assumed sebesar 4,339 dan nilai Significant (2-tailed) sebesar 0,001 lebih kecil dari level of significant $5 \% \quad(0,001<0,050)$. Dengan demikian dapat disimpulkan bahwa terdapat perbedaan rata-rata abnormal return antara portofolio winner dan portofolio looser.

\section{h. Agustus 2005-2009}

Hasil pengujian independent sample t-test menunjukkan nilai $F$ hitung levence's test sebesar 0,395 dan nilai Significant sebesar 0,542 karena probabilitas $>0,050$ maka memiliki variance yang sama, sehingga analisis uji beda $t$-test menggunakan asumsi equal variance assumed. Dari kolom $t$-test terlihat bahwa nilai $t$ pada equal variance assumed sebesar 2,459 dan nilai Significant (2-tailed) sebesar 0,030 lebih kecil dari level of significant $5 \% \quad(0,030<0,050)$. Dengan demikian dapat disimpulkan bahwa terdapat perbedaan rata-rata abnormal return antara portofolio winner dan portofolio looser.

\section{i. September 2005-2009}

Hasil pengujian independent sample t-test menunjukkan nilai $F$ hitung levence's test sebesar 0,550 dan nilai Significant sebesar 0,472 karena probabilitas $>0,050$ maka memiliki variance yang sama, sehingga analisis uji beda $t$-test menggunakan asumsi equal variance assumed. Dari kolom t-test terlihat bahwa nilai $t$ pada equal variance assumed sebesar 1,412 dan nilai Significant (2-tailed) sebesar 0,183 lebih besar dari level of significant 5\% $(0,183>0,050)$. Dengan demikian dapat disimpulkan bahwa tidak terdapat perbedaan rata-rata abnormal return antara portofolio winner dan portofolio looser. 
JURNAL NOMINA / VOLUME II NOMOR II / TAHUN 2013

j. Oktober 2005-2009

Hasil pengujian independent sample t-test menunjukkan nilai $F$ hitung levence's test sebesar 0,717 dan nilai Significant sebesar 0,414 karena probabilitas >0,050 maka memiliki variance yang sama, sehingga analisis uji beda $t$-test menggunakan asumsi equal variance assumed. Dari kolom $t$-test terlihat bahwa nilai $t$ pada equal variance assumed sebesar 3,084 dan nilai Significant (2-tailed) sebesar 0,009 lebih kecil dari level of significant 5\% $(0,009<0,050)$. Dengan demikian dapat disimpulkan bahwa terdapat perbedaan rata-rata abnormal return antara portofolio winner dan portofolio looser.

\section{k. November 2005-2009}

Hasil pengujian independent sample t-test menunjukkan nilai $F$ hitung levence's test sebesar 3,730 dan nilai Significant sebesar 0,077 karena probabilitas $>0,050$ maka memiliki variance yang sama, sehingga analisis uji beda t-test menggunakan asumsi equal variance assumed. Dari kolom t-test terlihat bahwa nilai $t$ pada equal variance assumed sebesar 2,204 dan nilai Significant (2-tailed) sebesar 0,048 lebih kecil dari level of significant $5 \% \quad(0,048<0,050)$. Dengan demikian dapat disimpulkan bahwa terdapat perbedaan rata-rata abnormal return antara portofolio winner dan portofolio looser.

\section{l. Desember 2005-2009}

Hasil pengujian independent sample t-test menunjukkan nilai $F$ hitung levence's test sebesar 1,601 dan nilai Significant sebesar 0,230 karena probabilitas >0,050 maka memiliki variance yang sama, sehingga analisis uji beda $t$-test menggunakan asumsi equal variance assumed. Dari kolom t-test terlihat bahwa nilai $t$ pada equal variance assumed sebesar 0,982 dan nilai Significant (2-tailed) sebesar 0,346 lebih besar dari level of significant $5 \% \quad(0,346>0,050)$. Dengan demikian dapat disimpulkan bahwa tidak terdapat perbedaan rata-rata abnormal return antara portofolio winner dan portofolio looser. 


\section{JURNAL NOMINA / VOLUME II NOMOR II / TAHUN 2013}

\section{Pembahasan}

Hipotesis yang diajukan dalam penelitian ini adalah Terjadi overreaction terhadap saham perusahaan manufaktur di Bursa Efek Indonesia (BEI) periode 2005-2009 dengan melihat terdapat perbedaan rata-rata cumulative abnormal return antara portofolio winner dan partofolio looser. Dengan adanya perbedaan rata-rata cumulative abnormal return antara portofolio winner dan partofolio looser secara konsisten dan signifikan maka saham perusahaan manufaktur di Bursa Efek Indonesia (BEI) pada periode tersebut mengalami gejala overreaction.

Hasil pengujian hipotesis dengan uji beda (independet sample $t$ test) menggunakan program SPSS 21 for Windows untuk menemukan adanya perbedaan rata-rata cumulative abnormal return antara portofolio winner dan partofolio looser sebagai indikator terjadinya overreaction, dihasilkan bahwa nilai Significant (2-tailed) pada kolom t-test bulan Januari 2005-2009, Februari 2005-2009, Mei 2005-2009, Juni 2005-2009, September 2005-2009, dan Desember 2005-2009 memiliki nilai lebih besar dari level of significant 5\% (0,050) yaitu sebesar 0,399, 0,539, 0,222, $0,487,0,183$, dan 0,346 . Hal ini berarti tidak terdapat perbedaan rata-rata cumulative abnormal return antara portofolio winner dan partofolio looser sehingga pada bulan Januari 2005-2009, Februari 2005-2009, Mei 20052009, Juni 2005-2009, September 2005-2009, dan Desember 2005-2009 tidak terjadi gejala Overreaction. Sedangkan hal berbeda terjadi pada bulan Maret 2005-2009, April 2005-2009, Juli 2005-2009, Agustus 20052009, Oktober 2005-2009, dan November 2005-2009 yang masing-masing memiliki nilai probabilitas lebih kecil dari level of significant $5 \%(0,050)$ yaitu masing-masing sebesar 0,028, 0,011, 0,001, 0,030, 0,009, dan 0,048. Hal ini berarti terdapat perbedaan rata-rata cumulative abnormal return antara portofolio winner dan partofolio looser sehingga pada bulan Maret 2005-2009, April 2005-2009, Juli 2005-2009, Agustus 2005-2009, Oktober 2005-2009, dan November 2005-2009 terjadi gejala overreaction. 
Berdasarkan ulasan diatas maka dapat di ambil rata-rata bahwa Significant (2-tailed) pada kolom t-test lebih besar jika dibandingkan dengan nilai Level of Significant $5 \%$.

Tabel Significant (2-tailed) 2005-2006

\begin{tabular}{|l|r|}
\hline \multicolumn{1}{|c|}{ Bulan } & $\begin{array}{l}\text { Sig. }(2- \\
\text { tailed })\end{array}$ \\
\hline Januari & 0,399 \\
Februari & 0,539 \\
Maret & 0,028 \\
April & 0,011 \\
Mei & 0,222 \\
Juni & 0,487 \\
Juli & 0,001 \\
Agustus & 0,030 \\
September & 0,183 \\
Oktober & 0,009 \\
November & 0,048 \\
Desember & 0,346 \\
\hline Total & 2,303 \\
Rata-rata Significant (2- & \\
tailed) 2005-2009 & 0,192 \\
\hline
\end{tabular}

Berdasarkan tabel tersebut dapat dilihat secara rata-rata bahwa nilai rata-rata Significant (2-tailed) sebesar 0,192 lebih besar dari Level of Significant 5\% $(0,192>0,050)$ hal ini membuktikan bahwa tidak terjadi overreaction yang signifikan. Overreaction dapat di lihat pada bulan Maret 2005-2009, April 2005-2009, Juli 2005-2009, Agustus 2005-2009, Oktober 2005-2009, dan November 2005-2009. Overreaction terjadi tidak dalam kurun waktu yang konstan lama, tetapi terjadi secara terpisah-pisah atau sparatis. Hal ini bisa disebabkan karena tingkat konsistensi terjadinya overreaction pada bulan Maret 2005-2009, April 2005-2009, Juli 20052009, Agustus 2005-2009, Oktober 2005-2009, dan November 2005-2009 tinggi. 


\section{JURNAL NOMINA / VOLUME II NOMOR II / TAHUN 2013}

\section{E. PENUTUP}

\section{Kesimpulan}

Berdasarkan data dan perhitungan serta analisis dan pembahasan yang telah dilakukan, maka penelitian berhasil menyimpulkan bahwa hasil penelitian menunjukkan tidak terjadi overreaction signifikan. Berdasarkan hal tersebut bahwa tidak terjadi adanya overreaction pada pasar saham di Bursa Efek Indonesia (BEI) khususnya pada saham manufaktur yang tergabung dalam Indeks LQ45 pada periode 2005-2009. Hal ini didukung dengan adanya hasil uji beda independent sample t-tast bahwa tidak terdapat perbedaan rata-rata cumulative abnormal return antara portofolio winner dan partofolio looser pada bulan Januari 2005-2009, Februari 2005-2009, Mei 2005-2009, Juni 2005-2009, September 2005-2009, dan Desember 2005-2009 yaitu sebesar 0,399, 0,539, 0,222, 0,487, 0,183, 0,346 dan nilai Significant (2-tailed) 2005-2009 sebesar 0,192 lebih besar dari Level of Significant 5\%. Perbedaan rata-rata cumulative abnormal return antara portofolio winner dan partofolio looser hanya terjadi pada bulan Maret 2005-2009, April 2005-2009, Juli 2005-2009, Agustus 20052009, Oktober 2005-2009, dan November 2005-2009. Hal tersebut bisa disebabkan karena tingkat konsistensi terjadinya overreaction pada bulan tersebut tinggi dan Overreaction terjadi tidak dalam kurun waktu yang konstan lama, tetapi terjadi secara terpisah-pisah atau sparatis.

\section{Saran}

Berdasarkan atas hasil analisis dan pembahasan serta beberapa kesimpulan dan keterbatasan pada penelitian ini, maka dapat disarankan sebagai berikut:

a. Bagi Investor

Bagi para investor diharapkan berhati-hati apabila bermaksud menggunakan strategi berkebalikan (Contrarian Strategy) karena berdasarkan penelitian ini gejala overreaction tidak terbukti terjadi di Bursa Efek Indonesia khususnya pada saham perusahaan manufaktur yang tergabung dalam Indeks LQ 45. 
b. Bagi Akademisi dan Peneliti yang akan Datang

Bagi para Akademisi maupun Peneliti yang akan datang, apabila akan mengadakan penelitian yang sejenis sebaiknya menggunakan periode pengamatan yang lebih panjang (lebih dari 5 tahun) agar hasil penelitian lebih baik dan sampel yang diteliti sebaiknya mewakili masing-masing jenis industri secara proposional.

\section{F. DAFTAR PUSTAKA}

Ang, Robert. (2003). Pasar Modal Indonesia. Jakarta: Mediasoft Indonesia.

Darmadji, Tjiptono dan Fakhruddin, Hendy M. (2001). Pasar Modal di Indonesia. Jakarta: Salemba Empat.

De Bond, W dan R Thaler. (1985). "Does Security Analysts Overreact?". The American Economic Review. Volume 80.

Evana dan Eddy Herjanto. (2009). "Analisis Overreaction pada Saham-saham Unggulan di Bursa Efek Indonesia". Jurnal Organisasi dan Manajemen/Tahun II/03.

Horne, James C. Van. (1997) Prinsip-prinsip Manajemen Keuangan. buku satu. Jakarta: Salemba Empat.

Imam Ghozali. (2011). Aplikasi Analisis Multivariate dengan Program IBM SPSS 19. Semarang: Badan Penerbit Universitas Diponegoro.

Jogiyanto Hartono. (2008). Teori Portofolio dan Analisis Investasi. Edisi Kelima. Yogyakarta: BPFE Yogya.

Maria Rio Rita dan Yosef Budi Kurniawan. (2009). "Pengujian Overreaction Terhadap Portofolio Winner dan Portofolio Loser Pada Saham LQ 45". Telaah Bisnis. Volume 10. Nomor 2.

Nur Indriantoro dan Bambang Supomo. (2002). Metode Penelitian Bisnis untuk Akuntansi dan Manajemen, Edisi Pertama. Yogyakarta: BPFE.

Purbayu Budi Santoso dan Ashari. (2005). Analisis Statistik dengan Microsoft Excel dan SPSS. Yogyakarta: Penerbit Andi.

Rahmawati dan Tri Suryani. (2005). "Over Reaksi Pasar Terhadap Harga Saham Perusahaan Manufaktur di Bursa Efek Jakarta". SNA VIII Solo. 
JURNAL NOMINA / VOLUME II NOMOR II / TAHUN 2013

Sunariyah. (2011). Pengantar Pengetahuan Pasar Modal. Yogyakarta: Unit Penerbit dan Percetakan.

Sugiyono. (2010). Statistika untuk Penelitian. Bandung: Alfa Beta.

www.idx.co.id (diakses tanggal 8 Oktober 2012 sampai dengan 16 Januari 2013). 